\title{
Islamic Social Contract on Finance for Muslim Minorities
}

\author{
Dr. Mohammad Manzoor Malik
}

\section{Introduction}

In my earlier published article "What Muslim Minorities Should do in Absence of Islamic Banking and Finance?" I made a conclusion that for the economic development of Muslim minorities "the option which remains before Muslim minorities before states will make Islamic banking and finance a reality is to find a way within the given legal-financial framework with the spirit of religious values and ethics".

Any effort by Muslim minorities to enhance their economic condition and moving towards progress should be based on a social contract. When regulations and laws are not by their letter Islamic in their nature then only upholding an Islamic social contract on finance could help Muslim minorities to provide a solid base, confidence, trust, and foundation for their economic and business initiatives including investment and finance. The whole economic activity is actually investment and finance and it has to be based on such a special social contract.

\section{Islamic Social Contract for Investment and Finance}

Islamic business ethics is a vast and expanding subject as the current forms of economical activities are being discussed and, at the same time, new forms of businesses and modes of investment and finance are emerging day by day. Demanding a religious social structure or institutions becomes meaningless and failure for those who do not have or could not keep the appropriate religiosity in their lives and character. That is why a legal mechanism becomes necessary to 
safeguard those who may get abused by faulty people. However, this legal mechanism is absent in those countries wherein Muslim minorities live in, therefore, one has to remain more careful and selective in engaging into any investment or finance dealings. On the other hand, it becomes necessary for those who work out businesses together to have strict adherence to Islamic business ethics and general ethical virtues of Islam.

Honesty, truthfulness, respect, etc are general virtues in Islamic ethics that should be applied and upheld by the people who are interested in conducting business activities. These virtues are relevant to both investment and finance. However, any Islamically shaped social contract on which investment and finance should be based in a country - wherein shariah is not the law of the state, and legally accepted businesses and investment and finance frameworks are not Islamic in their nature - should be based on the following cardinal virtues in Islamic ethics.

\section{Taradi (Mutual Consent)}

The first virtue is that finance and investment should be based on mutual consent. The parties involved in a financial dealing should not force each other against their will. As it is mentioned in the Quran, Verse (4:29), : "O you who believe! Eat not up your property among yourselves unjustly except it be a trade amongst you, by mutual consent. And do not kill yourselves (nor kill one another). Surely, Allah is Most Merciful to you." This mutual consent is the base for the uqood (contracts) and shuroot (conditions). It is also the foundation for the recommended mode of litigation i.e, tabkeem (arbitration). To apply this concept in a financial environment which is not governed by shariah laws, the parties dealing with each other should have an explicit pledge that in a situation wherein a dispute may arise and the governing laws of the country may put one of the 
parties at disadvantage, the other party should not take the benefit of the situation, but should turn to the mutually accepted mode of litigation and that is Tabkeem (Arbitration).

\section{Uqood (Contracts)}

The second virtue on which the social contract should be based is uqood (contracts). It is a religious obligation (farad/wajib) for a Muslim to uphold his contract which is valid (Sabih) agreement. The Quran, verse (5:1), states that " $\mathrm{O}$ you who have believed, fulfill [all] contracts..."

In a business environment which is not controlled by Shariah laws, there are many forms of businesses, finance and investment types which come under purview of laws for corporations, partnership, agency, mortgage, contracts, bail, sale of goods, hire purchase etc. These laws have most items, conditions, articles, and very essential components which are subject to the contract without any definite binding. There is enough freedom for contracting parties to come up with agreements of their own like and preferences. Therefore, it becomes work for the contracting persons coming from Muslim minorities to come up with contracts which are shariah based. A contract (aqad) should be clear and its words should not confuse the contracting parties. A contract (aqad) always includes conditions (shurrot). Therefore, the next important virtue is to follow the agreed upon conditions.

\section{Shurrot (Conditions)}

Shuroot (Conditions) is the third cardinal virtue of the social contract. Every contract has conditions which are agreed upon by the contracting parties with mutual consent such conditions if being valid and complying Shariah are necessary to be respected by the parties involved in any business deal. Contracts 
are partly comprised of Shuroot (Conditions) therefore it becomes obligatory for a Muslim to follow the agreed upon conditions as the Quran, verse (5:1), states : "O you who have believed, fulfill [all] contracts...". Furthermore, as it is narrated in Sahih al-Bukhari that "Muslims are bound by all the conditions they have agreed upon." And these conditions should be valid and in agreement with Islamic business ethics as it is reported in other narration (hadith) in al-Tirmidhi that states: "Muslims are bound by all the conditions they have agreed upon, unless the contractual conditions are against the principles of Islam in the way of making something unlawful as lawful or lawful as unlawful."

In applying the above concept to business environment in which Muslim minorities live in, it becomes necessary for the contracting parties in any type of business to follow Islamically valid conditions as most conditions in business partnerships and dealings are subject to contract in civil and common laws. Therefore, there is enough space for having suitable conditions as part of any contract.

\section{Iifa-ul-ahad (Fulfilling the Pledge)}

Disputes, conflicts, and disagreements etc do happen and can happen between the involved parties in any type of business. Therefore, the Islamic contract on finance for Muslim minorities should be based on one more virtue and that is keeping the pledge (iifa-ul-ahad). The pledge should be made and upheld by the contracting parties, that in any case of dispute between them, they will turn to Tabkeem (Arbitration), so none of them may get abused by misapplication of the common law. And keeping such a pledge once made becomes obligatory for a Muslim as the Quran, verse (16:91), states "Fulfill any pledge you make in Allah's name and do not break oaths after you have sworn them, for you have made Allah your surety: Allah knows everything you do". 
And furthermore the Quran states, verse (17:34),"Honor your pledges: you will be questioned about your pledges".

\section{Mode of Litigation and Conflict Resolution}

Tabkeem (Arbitration) is the best mechanism for resolution of any dispute and conflict between the involved parties in a business that is based on Islamic principles. This method is necessary because of the absence of Islamic laws for business, finance, and investment in the countries where Muslim minorities are present. Applying common law to such business dealings will be misapplication of the law and could result in further abuse of injured parties. And the good thing is that arbitration is even accepted in common law. Therefore, Muslim minorities should take legal benefit of such provision.

On the subject of Tabkeem (arbitration) the Quran, verse ( 4: 35), states: "If you fear a breach between them (the man and his wife), appoint (two) arbitrators, one from his family and the other from her's; if they both wish for peace, Allah will cause their reconciliation. Indeed Allah is Ever All Knower, Well Acquainted with all things". Furthermore, Tabkeem (Arbitration) should be based on the important virtue and that is Adil (Justice). In any proceeding and decision making the parties and the learned person or a group of learned persons who may be part of the arbitration should not lose the sight of adil (justice). The Quran, verse (4:58) states "Verily! Allah commands that you should render back the trusts to those, to whom they are due; and that when you judge between men, you judge with justice". 